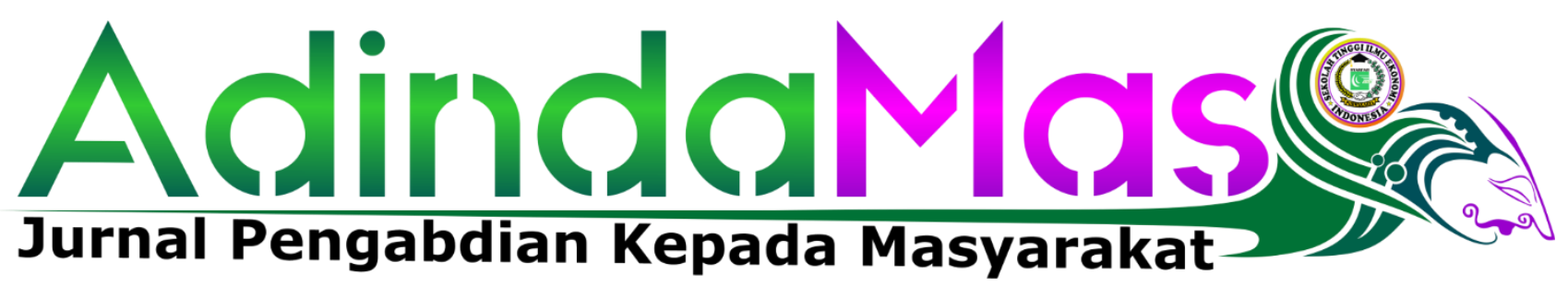

Volume 1 Nomor 1, Juli 2021

\title{
Pemberdayaan Ekonomi Masyarakat Berbasis Ekonomi Kreatif Di Desa Wanakerta Kec. Bungursari Purwakarta
}

\author{
Ahmad Damiri ${ }^{1}$, Jalaludin ${ }^{2}$, Tri Susanti ${ }^{3}$, Ayu Fajar Setiawati ${ }^{4}$ \\ 1,2Sekolah Tinggi Iilmu Ekonomi Syariah (STIES) Indonesia Purwakarta \\ 1ahmaddamiri@sties-purwakarta.ac.id \\ 2jalaludin@sties-purwakarta.ac.id \\ 3,4 Mahasiswa Sekolah Tinggi Iilmu Ekonomi Syariah (STIES) Indonesia Purwakarta \\ 3trisusanti@gmail.com \\ ${ }^{4}$ ayufajarsetiawati@gmail.com
}

\begin{abstract}
ABSTRAK
Pergeseran orientasi ekonomi dunia yang mengedepankan aset sumber daya manusia ini menyebabkan persaingan luar biasa dalam dunia kreatif (global competition of talents). Pembangunan pedesaan melalui industrialisasi pertanian atau peningkatan produksi pangan berbasikan penegembangan wilayah serta berbasiskan pertumbuhan ekonomi. Desa Wanakerta Kecamatan Bungursari Kabupaten Purwakarta adalah desa yang berbasis pertanian dan perkebunan, dan beberapa potensi ada Usaha Mikro dan Kecil diantaranya pengrajin lampu karakter, Tas Manik, dan Kripik Pisang. Dan saat ini di desa tersebut sangat diperlukan adanya pengembangan-pengembangan usaha yang tepat guna. Pelaksanaan pendampingan dan pengembangan masyarakat merupakan salah satu tujuan dari kegiatan PKM yang diharapkan mampu untuk dapat menyelesaikan permasalahan yang ada di masyarakat Desa Wanakerta, baik di bidang perekonomian, keagamaan, sosial dan budaya, pemerintahan desa, maupun di bidang pendidikan dan kesehatan. Melalui pendampingan terhadap masyarakat, kegiatan PKM ini melakukan penggalian data tentang persoalan atau kondisi masyarakat sekitar yang selanjutnya dirumuskan dalam bentuk program kerja dan realisasinya yang diharapkan dapat menjawab persoalan yang ada bersama dengan masyarakat. Kemudian program kerja yang
\end{abstract}


dirumuskan telah terealisasi kurang lebih $90 \%$ sesuai dengan kemampuan peserta PKM, meskipun masih terdapat kendala dalam pelaksanaannya.

Kata kunci - Pemberdayaan Ekonomi, Ekonomi Kreatif.

\section{ABSTRACT}

This shift in the orientation of the world economy that prioritizes human resource assets has led to extraordinary competition in the creative world (global competition of talents). Rural development through agricultural industrialization or increasing food production based on regional development and based on economic growth. Wanakerta Village, Bungursari Sub-district, Purwakarta Regency is a village based on agriculture and plantations, and several potentials exist for Micro and Small Enterprises including character lamp craftsmen, Bead Bags, and Banana Chips. And at this time in the village it is very necessary for appropriate business developments. The implementation of community assistance and development is one of the goals of PKM activities which are expected to be able to solve problems that exist in the Wanakerta Village community, both in the economic, religious, social and cultural fields, village government, as well as in the fields of education and health. Through assistance to the community, this PKM activity collects data on problems or conditions of the surrounding community which is then formulated in the form of a work program and its realization which is expected to answer problems that exist together with the community. Then the formulated work program has been realized approximately $90 \%$ according to the ability of PKM participants, although there are still obstacles in its implementation.

Keywords - Economic Empowerment, Creative Economy.

\section{PENDAHULUAN}

Arus globalisasi dan liberalisasi ekonomi dunia bergerak begitu cepat mendorong semakin meningkatnya keterbukaan hubungan ekonomi antar-bangsa dan mendorong persaingan yang semakin meningkat ${ }^{1}$. Menurut Forum Ekonomi Dunia (World Economic Forum) tentang daya saing global, Indonesia dalam Laporan Indeks Daya Saing WEF 2016- 2017, posisi Indonesia tidak lebih baik dibandingkan dengan negara tetangganya di Asia Tenggara, seperti Thailand (34), Malaysia (25), dan Singapura (2). Namun, Indonesia masih unggul dibandingkan dengan Filipina (57), Vietnam (60), dan Laos (93). Meski skornya tetap $(4,52)$, posisi Indonesia melorot empat level setelah disalip sejumlah negara. ${ }^{2}$

1 Nasriah Akil, "Strategi Pengembangan Ekonomi Kreatif Kabupaten Wajo," Jurnal BISNIS E KEWIRAUSAHAAN 4, no. 4 (2015): 404-415.

${ }^{2}$ Siti Nur Azizah and Muhfiatun Muhfiatun, "Pengembangan Ekonomi Kreatif Berbasis Kearifan Lokal Pandanus Handicraft Dalam Menghadapi Pasar Modern Perspektif Ekonomi Syariah (Study Case Di Pandanus Nusa Sambisari Yogyakarta)," Aplikasia: Jurnal Aplikasi Ilmu-ilmu Agama 17, no. 2 (February 12, 2018): 63, http://ejournal.uin-suka.ac.id/pusat/aplikasia/article/view/1273.

ADINDAMAS (Jurnal Pengabdian Kepada Masyarakat), Volume 1, Nomor 1, Juli 2021 http://journal.sties-purwakarta.ac.id/index.php/adindamas/

ISSN: xxxx-xxxx (Media Online) xxxx-xxxx (Media Cetak) 
Daya saing Indonesia 2016-2017 berada di peringkat 41 atau turun empat peringkat dibanding posisi tahun lalu yang berada di urutan 37. Seperti dimuat dalam Global Competitiveness Index, meski Indonesia telah banyak melakukan reformasi di berbagai sektor, namun secara performance empat negara lain berhasil menggeser posisi Indonesia. ${ }^{3}$ Negara tersebut yakni Malta, India, Kuwait dan Azerbaijan. Pergeseran orientasi ekonomi dunia yang mengedepankan aset sumber daya manusia ini menyebabkan persaingan luar biasa dalam dunia kreatif (global competition of talents). ${ }^{4}$

Pembangunan pedesaan melalui industrialisasi pertanian atau peningkatan produksi pangan berbasikan pengembangan wilayah serta berbasiskan pertumbuhan ekonomi serta pendekatan pembangunan pedesaan yang berbasis pada ekonomi dan sosial kreatif ini perlu dipahami bagaimana kekuatannya untuk menggerakkan perekonomian desa. 5

Sejarah berdirinya Desa Wanakerta, berawal pada tahun 1984 ketika Desa Wanakerta dimekarkan menjadi Desa Cinangka dan Desa Wanakerta, Pemekaran tersebut merupakan pemekaran lanjutan dari pemekaran sebelumnya, yaitu pemekaran Desa Cibungur yang menjadi desa induk diawal berpisahnya Kabupaten Purwakarta dan Kabupaten Subang pada tahun 1968. Saat sebelum dimekarkan pusat pemerintahan Desa Wanakerta terletak di wilayah Desa Cinangka sekarang.

Menurut para saksi sejarah tentang pendirian desa wanakerta ini, nama Wanakerta dipilih setelah melalui proses Musyawarah para tetua adat, tokoh masyarakat, tokoh agama dan tokoh pemuda. Wanakerta berasal dari kata Wana yang berarti hutan dan Kerta yang berarti ramai , dahulunya wilayah desa Wanakerta memang merupakan wilayah hutan jati yang luas, yang merupakan bagian dari KRPH Cibungur. Tidak banyak data dan fakta tertulis yang bisa diperoleh, hanya kesaksian dari para pelaku sejarah yang dijadikan acuan. Suatu yang menarik dari kesaksian mereka adalah berbicara masalah desa berarti berbicara masalah pemimpinnya atau kepala desa nya. Kepala Desa atau yang dulu disebut dengan lurah, merupakan sosok yang kharismatik yang selalu didengar oleh masyarakatnya, beralasan mengingat pemilihan lurah dulu tidak dilihat dari latar belakang pendidikan atau pengetahuannya, melainkan dari apa yang telah diberikannya kepada masyarakat banyak dan terkadang kemampuan lain yang tidak dimiliki sebagian besar masyarakat, seperti ilmu kanuragan, atau ilmu supranatural lainnya.

${ }^{3}$ Moch Cahyo Sucipto, “The Human Rights In Islam (The Study Of Al-Muwafaqat By Imam Al-Syathibi)," EKSISBANK (Ekonomi Syariah dan Bisnis Perbankan) 2, no. 2 (2018): 1-5.

4 Azizah and Muhfiatun, "Pengembangan Ekonomi Kreatif Berbasis Kearifan Lokal Pandanus Handicraft Dalam Menghadapi Pasar Modern Perspektif Ekonomi Syariah (Study Case Di Pandanus Nusa Sambisari Yogyakarta)."

${ }^{5}$ Budi Sitorus and Tulus Irfan Harsono Sitorus, "Dukungan Transportasi Logistik Dan Daya Saing Indonesia Dalam Menghadapi Masyarakat Ekonomi Asean," JURNAL MANAJEMEN TRANSPORTASI DAN LOGISTIK 4, no. 2 (September 11, 2017): 137, http://ejournal.stmt-trisakti.ac.id/index.php/jmtranslog/article/view/70.

ADINDAMAS (Jurnal Pengabdian Kepada Masyarakat), Volume 1, Nomor 1, Juli 2021 http://journal.sties-purwakarta.ac.id/index.php/adindamas/

ISSN: $x x x x-x x x x$ (Media Online) xxxx-xxxx (Media Cetak) 
Pada awal berdirinya, dipimpin oleh seorang Kepala Desa yaitu Uyon yang berasal dari Kp. Cikiara RT 003/001, Desa Wanakerta masih terdiri dari 4 kampung, 2 dusun, 10 RT dan 2 RW. Pada perkembangannya kemudian diawal tahun 90-an hutan jati di wilayah Desa Wanakerta beralih fungsi menjadi kawasan industri, yaitu Bukit Indah City yang kemudian berubah menjadi Kota Bukit Indah. Seiring berdirinya kawasan industri dibangun pula kawasan Perumahan Umum sebagai bagian dari fasilitas kawasan industri tersebut. Maka sejak tahun 2008 Desa Wanakerta memiliki 15 RT dan 4 RW. Kawasan Perumahan Umum, yaitu Perum Bukit Indah Permai menjadi wilayah administratif Desa Wanakerta sejak saat itu.

Visi dan misi desa Wanakerta berangkat dari hasil pengkajian keadaan desa yang bercerita tentang kebutuhan dan keadaan desa tersebut, tapi sering kali visi dan misi desa justru berangkat dari keinginan pribadi seorang kepala desa. Hal tersebut bisa jadi menjadi penyebab mengapa akhirnya visi dan misi desa tidak selaras dengan kebutuhan dan keadaan desa itu. Visi dan misi harus digagas dari sebuah musyawarah desa yang dihadiri oleh seluruh lapisan masyarakat. Keselarasan visi dan misi dari seorang Kepala Desa dengan masukan dari seluruh lapisan masyarakat itulah yang kemudian dituangkan dalam Visi dan Misi Desa dalam dokumen Rencana Pembangunan Jangka Menengah Desa (RPJMDes).

Rencana pembangunan yang telah terbungkus dengan visi dan misi desa inilah yang kemudian akan memperlihatkan jati diri desa kepada masyarakat secara luas.

Visi adalah suatu gambaran yang menantang tentang keadaan masa depan yang diinginkan dengan melihat potensi dan kebutuhan desa. Penyusunan Visi Desa Wanakerta dilakukan dengan pendekatan partisipatif dan pro aktif, dengan melibatkan pihak-pihak yang berkepentingan di Desa Wanakerta seperti pemerintahan desa, bamusdes, tokoh masyarakat, tokoh agama, lembaga masyarakat desa, pemuda, dan kaum perempuan.

Pertimbangan kondisi di desa sebagai satuan kerja wilayah pembangunan di Kecamatan Bungursari yang menitikberatkan di bidang sarana prasarana, perdagangan dan industri, maka Desa Wanakerta menuangkan Visi Desa nya, juga dengan pertimbangan Visi Desa sebelumnya seperti tertuang dalam Perdes Desa Wanakerta Nomor 3 tahun 2014, adalah :

“Terlaksananya Pemerintahan Desa Yang Amanah, Serta Terwujudnya Masyarakat Desa Wanakerta Yang Menjunjung Tinggi Nilai Adat, Gotong Royong, Persaudaraan Melalui Partisipasi Pembangunan Yang Berwawasan Lingkungan Dan Bertanggungjawab Berdasarkan Musyawarah Mufakat."

Penjabaran dari Visi Kepala Desa Wanakerta tersebut adalah sebagai berikut :

a. Arah

Amanah : mengandung makna seluruh perangkat dan aparat pemerintahan Desa Wanakerta menjaga kepercayaan yang diberikan masyarakat Desa .

b. Landasan

ADINDAMAS (Jurnal Pengabdian Kepada Masyarakat), Volume 1, Nomor 1, Juli 2021 http://journal.sties-purwakarta.ac.id/index.php/adindamas/

ISSN: xxxx-xxxx (Media Online) xxxx-xxxx (Media Cetak) 
Gotong Royong : mengandung makna bahwa masyarakat Desa Wanakerta masih mewarisi adat dan kebiasaan nenek moyangnya dalam bekerja bahu membahu serta tolong menolong antar sesama warga.

Persaudaraan : mengandung makna konsep hidup ketimuran masih dipegang teguh ditengah masyarakat Desa Wanakerta yang pluraris yang beraneka ragam suku bangsa dan agama, wujud tenggang rasa diantara sesama warga masyarakat masih dipegang teguh.

c. Tujuan

Keberhasilan di semua bidang : memiliki makna bahwa Desa bercita-cita mewujudkan pembangunan di semua aspek kehidupan dengan pembangunan yang berwawasan lingkungan.

Misi Desa Wanakerta, selain penyusunan Visi juga telah ditetapkan misi-misi yang memuat suatu pernyataan atau implementasi dari kebijakan secara global dari Visi Desa Wanakerta tersebut. Penyusunan misi ini menggunakan pendekatan partisipatif dengan pertimbangan potensi, masalah, kebutuhan masyarakat dan urgensi atau kemendesakan skala prioritas. Maka Misi Desa Wanakerta yang merupakan jabaran dari Visi Desa adalah :

a. Mewujudkan Pemerintahan yang baik, cepat tanggap terhadap permasalahan yang terjadi di masyarakat;

b. Meningkatkan kegiatan-kegiatan agama, sosial, ekonomi, seni budaya, olahraga dan pendidikan;

c. Meningkatkan kualitas Sumber Daya Manusia;

d. Melestarikan nilai-nilai adat dan gotong royong dalam masyarakat;

e. Melaksanakan Pembangunan yang berwawasan lingkungan secara bertanggung jawab berdasarkan musyawarah mufakat.

Berdasarkan hasil pengamatan di Desa Wanakerta Kecamatan Bungursari Kabupaten Purwakarta Wilayah Desa Wanakerta adalah desa yang berbasis pertanian dan perkebunan, dan beberapa potensi ada Usaha Mikro dan Kecil diantaranya pengrajin lampu karakter, Tas Manik, dan Kripik Pisang. Dan saat ini di desa tersebut sangat diperlukan adanya pengembangan-pengembangan usaha yang tepat guna, mengingat dari sisi kesejahteraan di desa tersebut yang masih kurang. Howkins dalam bukunya The Creative Economy menemukan kehadiran gelombang ekonomi kreatif setelah menyadari pertama kali pada tahun 1996 ekspor karya hak cipta Amerika Serikat mempunyai nilai penjualan sebesar US\$ 60,18 miliar yang jauh melampaui ekspor sektor lainnya seperti otomotif, pertanian, dan pesawat. 6

Menurut Howkins ekonomi baru telah muncul seputar industri kreatif yang dikendalikan oleh hukum kekayaan intelektual seperti paten, hak cipta, merek, royalty dan desain. Ekonomi kreatif merupakan pengembangan konsep berdasarkan

${ }^{6}$ Akil, "Strategi Pengembangan Ekonomi Kreatif Kabupaten Wajo."

ADINDAMAS (Jurnal Pengabdian Kepada Masyarakat), Volume 1, Nomor 1, Juli 2021

http://journal.sties-purwakarta.ac.id/index.php/adindamas/

ISSN: xxxx-xxxx (Media Online) xxxx-xxxx (Media Cetak) 
aset kreatif yang berpotensi meningkatkan pertumbuhan ekonomi. 7 Strategi Mewujudkan Ekonomi Kreatif Untuk mengembangkan ekonomi kreatif, pemerintah Indonesia dibawah kepemimpinan presiden terpilih harus membuat beberapa strategi besar dan melaksanakan pembangunan secara terintegrasi antara masyarakat, swasta dan pemerintah. Beberapa strategi yang akan dilakukan sebagai berikut :

a. Menyiapkan insentif untuk memacu pertumbuhan industri kreatif berbasis budaya, mencakup perlindungan produk budaya, pajak, kemudahan memperoleh dana pengembangan, fasilitas pemasaran dan promosi, hingga pertumbuhan pasar domestik dan internasional;

b. Membuat roadmap industri kreatif yang melibatkan berbagai departemen dan kalangan termasuk swasta;

c. Membuat program komprehensif untuk menggerakkan industri kreatif melalui pendidikan, pengembangan SDM, desain, mutu dan pengembangan pasar;

d. Memberikan perlindungan hukum dan insentif bagi karya industri kreatif; Beberapa contoh produk industri kreatif yang dilindungi HKI-nya, di antaranya buku, tulisan, drama, tari, koreografi, karya seni rupa, lagu atau musik, dan arsitektur. Produk lainnya adalah paten terhadap suatu penemuan, merek produk atau jasa, desain industri, desain tata letak sirkuit terpadu dan rahasia dagang.

e. Pemerintah membentuk Indonesian Creative Council yang akan menjadi jembatan untuk menyediakan fasilitas bagi para pelaku industri kreatif.

f. Pemerintah menyelenggarakan lomba Indonesia Creative Idol (ICI), yang bertujuan untuk melestarikan dan mengembangkan industri kreatif.

\section{METODE}

\section{A. Tempat dan Waktu}

Kegiatan pengabdian kepada masyarakat tentang Pemberdayaan Ekonomi Masyarakat Berbasis Ekonomi Kreatif Di Desa Wanakerta Kec. Bungursari Purwakarta, ahri minggu, tanggal 18 Februari 2018. Tim PKM mengidentifikasi masalah sesuai dengan rencana kegiatan, sebagai berikut ;

- Pengelolaan potensi alam yang belum optimal

- Kemampuan dan keterampilan usaha yang masih kurang

- Dukungan lembaga-lembaga terkait yang belum optimal

- Pendapatan masyarakat yang relatif masih kurang

${ }^{7}$ Sigit Nugroho and Sujadmi Sujadmi, “Perlindungan Hukum Dan Analisis Potensi Desain Industri Pada Ekonomi Kreatif Yang Berbasis Ilmu Pengetahuan Yang Dihasilkan Oleh Umkm Di Kota Pangkalpinang," PROGRESIF: Jurnal Hukum 10, no. 2 (August 20, 2018), https://journal.ubb.ac.id/index.php/progresif/article/view/194.

ADINDAMAS (Jurnal Pengabdian Kepada Masyarakat), Volume 1, Nomor 1, Juli 2021 http://journal.sties-purwakarta.ac.id/index.php/adindamas/ 


\section{B. Ruang Lingkup dan Objek Pengabdian}

Objek yang menjadi sasaran dari kegiatan pengabdian kepada masyarakat ini adalah masyarakat dan para pelaku UKM Desa Wanakerta Kec. Bungursari Purwakarta Jawa Barat.

\section{Pendekatan atau teknik pengabdian}

Kegiatan pengabdian kepda masyarakat ini dilakukan dengan menggunakan pendekatan service learning, dengan melalui tiga tahapan, yakni tahapan persiapan, tahapan analisis, dan tahapan refleksi. Analisis Kebutuhan Analisis ini meliputi analisis kondisi masyarakat dan pemetaan kondisi masyarakat. Tahapan berikutnya adalah tahapan refleksi yakni Penyusunan program, Pelaksanaan program, Pelatihan Promosi dan Publikasi, Evaluasi program, Monitoring, dan Pembuatan laporan.

\section{HASIL DAN PEMBAHASAN}

Deskripsi Pelaksanaan Kegiatan Per-Bidang Kegiatan. Secara umum hasil kegiatan PKM merupakan upaya pemecahan masalah dan pemenuhan akan kebutuhan masyarakat serta tercapainya tujuan sebagai indikator keberhasilan. ${ }^{8}$ Hasil pelaksanaan program kerja PKM dapat dirasakan dari beberapa indikator yang muncul atau adanya perbedaan pada masyarakat sebelum dan sesudah pelaksanaan di Desa Wanakerta Kecamatan Bungursari Kabupaten Purwakarta Tahun 2018. Adapun rencana-rencana kegiatan yang berhasil direalisasikan dalam kegiatan PKM di Desa Wanakerta Kecamatan Bungursari Kabupaten Purwakarta adalah sebagai berikut :

A. Bidang Ekonomi

1. Mengadakan penyuluhan dan membantu meningkatkan pendapatan pengusaha pengrajin lampu karakter, Tas Manik, dan Kripik Pisang di Desa Wanakerta.

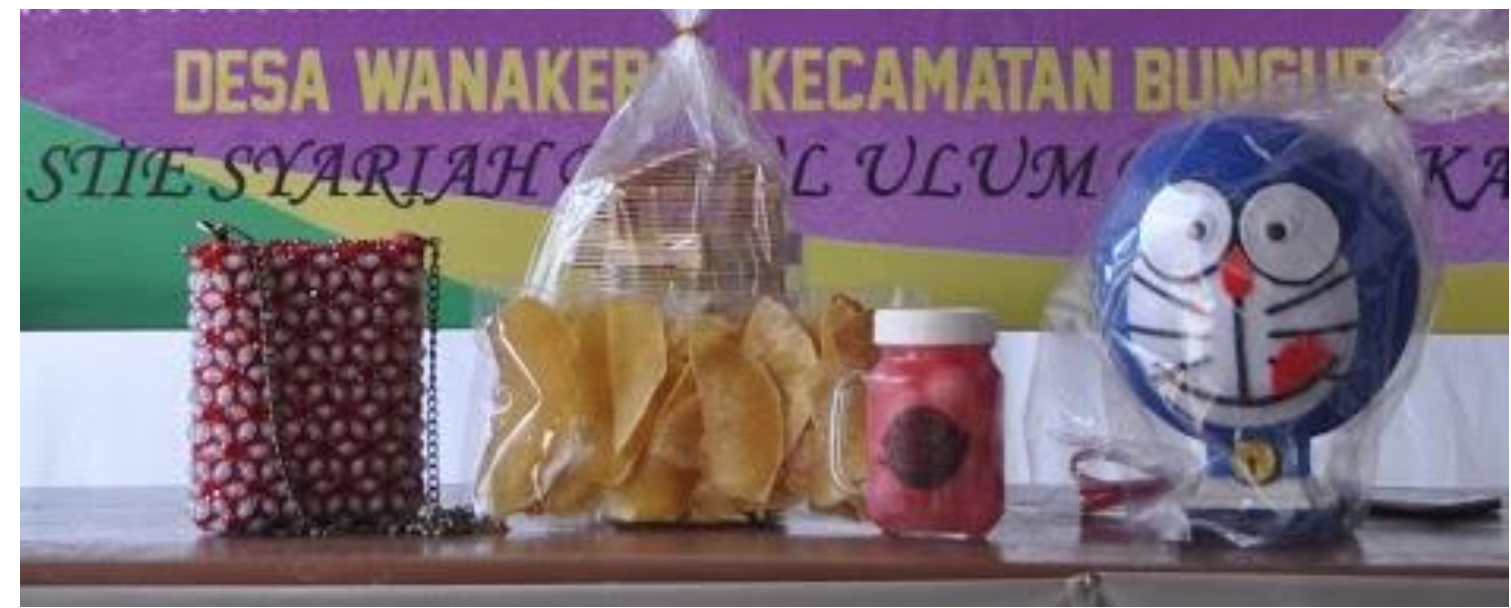

Gambar 3.1 Hasil Pelaku UKM di Desa Wanakerta Bungursari Purwakarta

8 Jalaludin Jalaludin and Heru Komarujaman, "Talent Management Dalam Meningkatkan Kinerja Lembaga KSPPS BMT Mitra Sadaya Cabang Purwakarta," EKSISBANK: Ekonomi Syariah dan Bisnis Perbankan 2, no. 1 (June 25, 2018), http://journal.sties-purwakarta.ac.id/index.php/EKSISBANK/article/view/9.

ADINDAMAS (Jurnal Pengabdian Kepada Masyarakat), Volume 1, Nomor 1, Juli 2021 http://journal.sties-purwakarta.ac.id/index.php/adindamas/

ISSN: xxxx-xxxx (Media Online) xxxx-xxxx (Media Cetak) 
2. Membantu pengusaha lampu karakter dalam proses produksi di Desa Wanakerta.

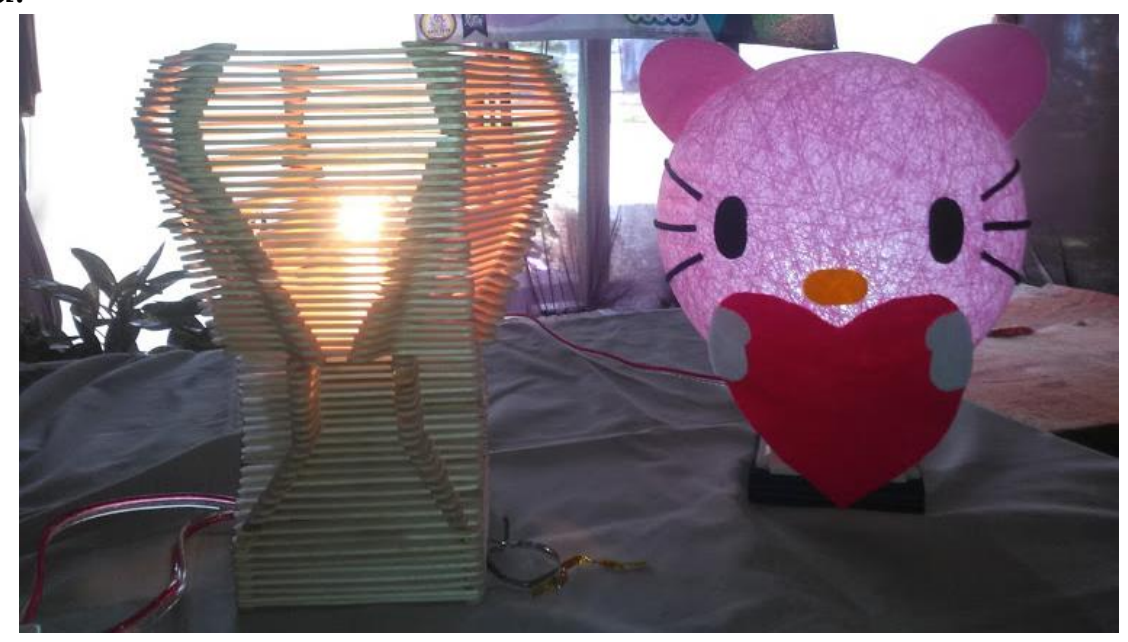

Gambar 3.2 Hasil Kerajinan Lampu Karakter

3. Membantu pengusaha Tas dalam proses produksi Tas manik di Desa Wanakerta.

4. Membantu pengusaha Kripik dalam proses produksi Kripik pisang di Desa Wanakerta.

5. Memberikan penyuluhan dan praktek mengenai pembuatan manisan dan dodol rambutan kepada ibu-ibu warga kampung Cimahi Desa Wanakerta. karena daerah tersebut salah satu penghasil rambutan, saat musim rambutan tiba, banyak sekali rambutan yang tidak termakan/ terjual, karena bosan, variasinya itu-itu saja. ${ }^{9}$ Supaya menghindari sifat "mubazir", maka dibuatlah pelatihan cara mengelola rambutan menjadi makan unik dan enak, serta bias menjadi nilai ekonomis salah satunya dibuat manisan dan dodol rambutan.

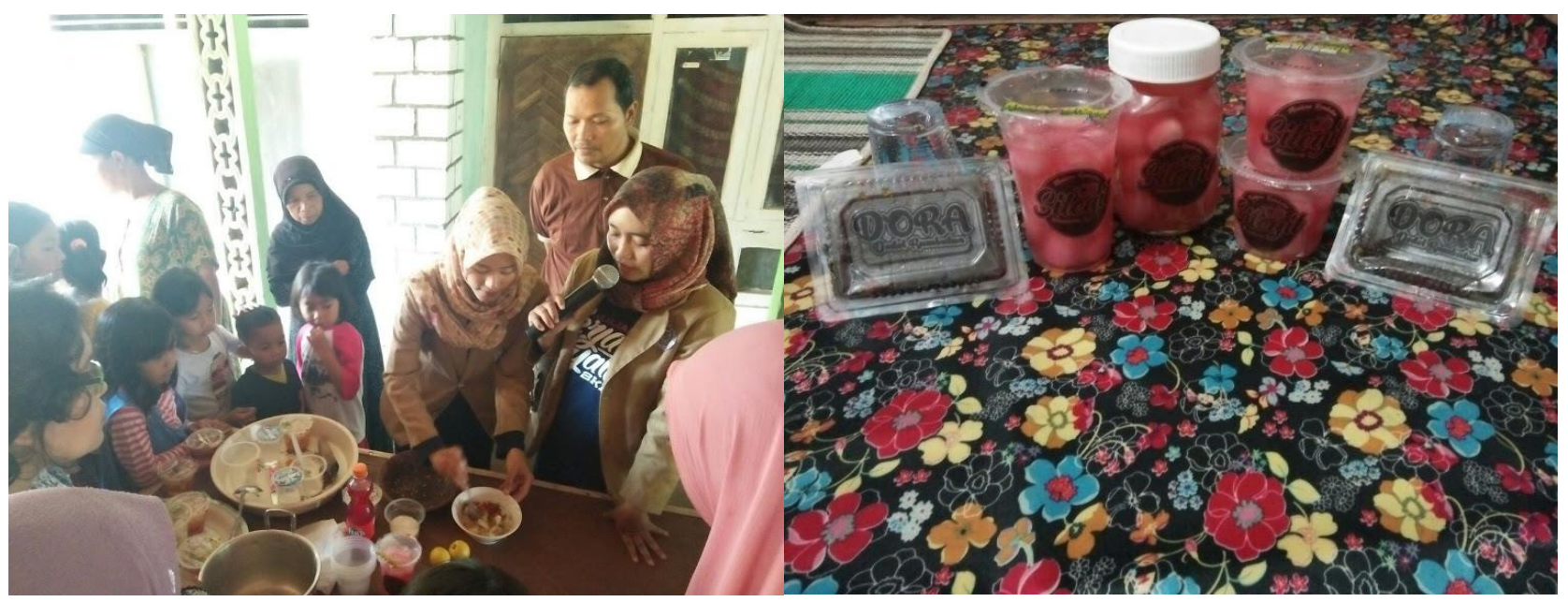

Gambar 3.3 Pelatihan Pembuatan Manisan dan Dodol Rambutan

${ }^{9}$ Lisa Dewi Anggraeni, Moch. Cahyo Sucipto, and Siti Rohmat, “Analisis Faktor Yang Mempengaruhi Masyarakat Muslim Menggunakan Jasa 'Bank Emok' Di Desa Cilalawi Kecamatan Sukatani Kabupaten Purwakarta," EKSISBANK (Ekonomi Syariah dan Bisnis Perbankan) 4, no. 2 (2018).

ADINDAMAS (Jurnal Pengabdian Kepada Masyarakat), Volume 1, Nomor 1, Juli 2021 http://journal.sties-purwakarta.ac.id/index.php/adindamas/

ISSN: xxxx-xxxx (Media Online) xxxx-xxxx (Media Cetak) 
6. Menyelenggarakan Bazar Produk UMKM yang ditujukan untuk menghadirkan produk-produk umkm yang telah menguti pelatihan dapat memasarkan produk tersebut kepada pasar. Dalam hal ini masyarakat desa wanakerta. Disamping hal tersebut juga bertujuan untuk mengedepankan produk-produk tersebut ketengah masyarakat, yang mana pada sebelumnya belum megetahui adanya produk-produk yang bernilai ekonomi disekitar yang luput untuk di kelola dan ditingkatkan.

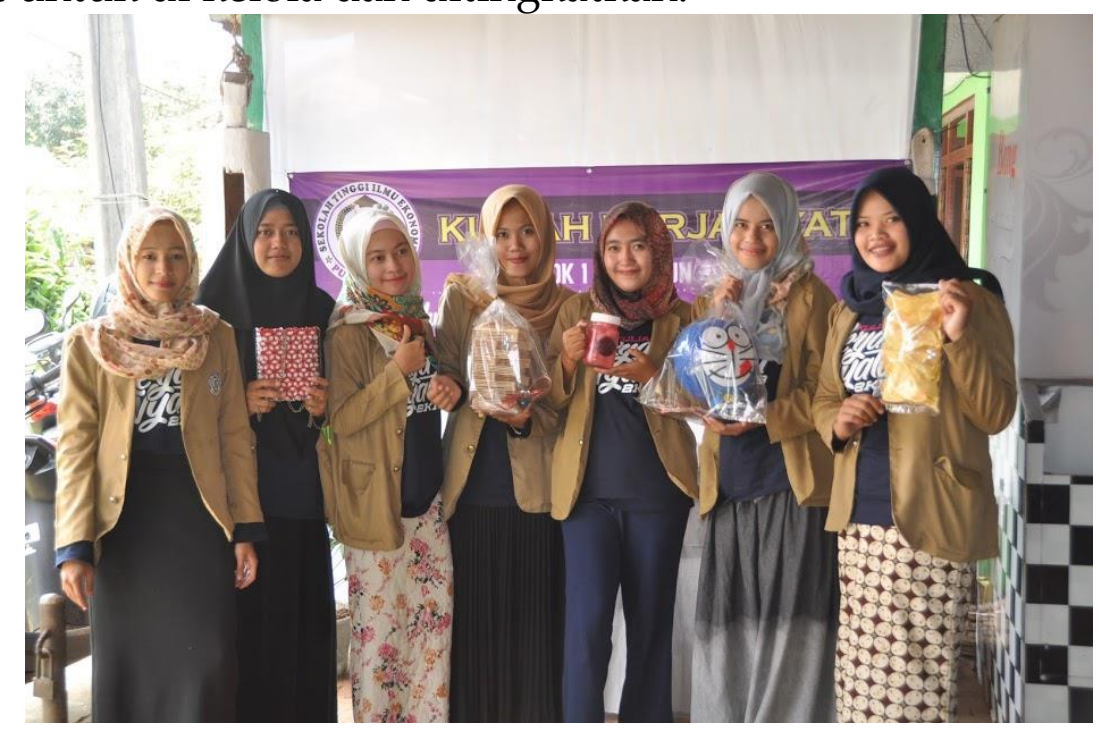

Gambar 3.4 Produk Bazar UKM Desa Wanakerta Bungursari Purwakarta

B. Bidang Keagamaan

1. Menghadiri pengajian bulanan di masjid jami kampung Cimahi Desa Wanakerta Bungursari Purwakarta, membantu acara dan konsumsi.

2. Memberikan bimbingan tata cara sholat dan mengajar mengaji anak-anak warga Kp. Cimahi Desa Wanakerta Bungursari Purwakarta yang dilaksanakan pada sore atau malam hari setelah waktu maghrib.

3. Menghadiri kegiatan pengajian rotib dan sholawatan dikampung cimahi Desa Wanakerta Bungursari Purwakarta.

C. Bidang Sosial dan Budaya

1. Turut telibat dalam pelaksanaan kegiatan jum'at bersih, pelaksanaan pemeliharaan kebersihan lingkungan melalui pembersihan salauran air dan dan sarana prasarana umum.

2. Kunjungan ke salah satu sanggar seni tari remaja dan melihat pelaksanaan belajar seni kelompok anak dan remaja di kampung Cimahi Desa Wanakerta Bungursari Purwakarta.

3. Mengikuti pelasanaan penertiban dan keamanan lingkungan melalui program ronda.

4. Turut serta dalam kegiatan gotong rotong perbaikan dan pembangunan mesjid jami di Desa Wanakerta Bungursari Purwakarta.

D. Bidang Pemerintahan Desa 
1. Menghadiri kegiatan minggon (Musyawarah Rencana Pembangunan Desa) malam mingguan di kantor desa / balai desa.

2. Merapikan arsip dan berkas di kantor Desa Wanakerta Bungursari Purwakarta.

3. Membantu staff kantor desa dalam surat menyurat.

4. Membantu monitoring petugas desa dalam pelaksanaan program beas perelek dilingkungan Rt dan Rw Desa Wanakerta Bungursari Purwakarta.

5. Berpartisipasi dalam kegiatan Distirbusi Beas Perelek melalui ATM Beas Desa.

6. Mengikuti kegiatan pemanfaatan limbah industri menjadai produk pakan ternak yang dikelola oleh karang taruna Desa Wanakerta Bungursari Purwakarta.

E. Bidang Pendidikan dan Kesehatan

1. Melakukan kunjungan-kunjungan ke sekolah dasar dan sekeolah Dasar dan Madrasah Ibtidaiyah untuk mengetahui pola belajar anak di sekolah.

2. Melakukan sosialisasi pendidikan di SD dan MI Desa Wanakerta Bungursari Purwakarta.

3. Membantu kegiatan KBM di sekolah, membantu mengisi kegiatan belajar mengajar yang kosong dikarenakan guru yang tidak bisa hadir untuk mengajar.

4. Membantu belajar tambahan (les private dan bimbingan belajar), membantu anakanak dalam belajar di luar sekolah di karenakan dengan mengadakan lest privat untuk menambah wawasan pengetahuan anak-anak yang tidak di berikan di sekolah.

5. Kegiatan diskusi dengan kepala sekolah, guru dan komite sekolah, mengadakan kegiatan diskusi dengan kepala sekolah dan komite sekolah untuk mengetahui pola belajar anak yang baik dan efektif.

6. Membantu anak-anak desa dengan memberikan edukasi bahasa inggris dan teknologi terkini, memberikan edukasi bahasa inggris dan teknologi dikarenakan masih kurang nya edukasi yang di berikan sekolah terutama bahasa inggris dan teknologi, karena di jaman sekarang bahasa inggris dan teknologi merupakan edukasi yang penting bagi masa depan mereka.

7. Memberikan pendidikan dan pelatihan kerajinan tangan dari limbah rumah seperti koran, botol pelastik dan sedotan menjadi produk bernilai seni dan memiliki nilai ekonomi.

8. Mengadakan kegiatan rutin belajar 2 kali dalam 1 hari bagi anak-anak desa yang belum bersekolah, mengadakan kegiatan rutin belajar 2 kali dalam sehari yaitu sesudah solat dzuhur (12:30) dan sesudah solat maghrib (18:30).

9. Mengikuti kegiatan posyandu Desa Wanakerta Bungursari Purwakarta.

10. Mengadakan senam sehat.

11. Mengadakan sosialisasi dan praktik sikat gigi sehat. 
12. Mengajak warga Desa Wanakerta untuk melakukan operasi semut di lingkungan sekitar Kp. Cimahi.

13. Melaksanakan kegiatan edukatif untuk anak dan remaja melalui lomba menggambar dan mewarnai.

14. Menyelenggarakan pentas seni tari untuk anak dan remaja. Memberikan ruang kepada anak-anak berbakat menjadi bagian yang sangat penting untuk perkembangan bakat dan minat dimasa mendatang.

Evaluasi dan Harapan Masyarakat (Stakeholders), adanya kegiatan PKM tentunya memberikan kesan dan harapan tersendiri bagi masyarakat. Maka evaluasi kegiatan dan harapan dari masyarakat berdasarkan bidang-bidang kegiatan, antara lain ;

1. Bidang Ekonomi

Para pelaku Usaha Mikro dan Kecil yang dikunjungi merasa terbantu dengan adanya kegiatan PKM ini, baik dari aspek produksi hingga dengan aspek pemasarannya. Harapan dari pelaku Usaha Mikro dan Kecil Desa Wanakerta yaitu adanya koperasi peminjaman modal untuk warga Desa Wanakerta agar mudah dalam memperoleh modal untuk usaha.

2. Bidang Keagamaan. Masyarakat Kp. Cimahi menyambut dengan baik ketika mengikuti pengajian bulanan "Rutinan" di masjid. Beberapa warga masyarakat Kp. Cimahi sangat antusias dengan kegiatan- kegiatan yang menjadi program kerja PKM.

3. Bidang Sosial dan Budaya. Begitu banyak kegiatan sosial dan budaya di Desa Wanakerta yang bisa diikuti dan dipelajari. Namun keterbatasan waktu ternyata tidak memungkinkan untuk mendalami semuanya.

4. Bidang Pemerintahan Desa. Bidang pemerintahan desa merupakan bidang yang tidak kalah penting dengan bidang yang lainnya, yang mana programprogram yang disusun dimaksudkan untuk membantu aparat desa dalam melaksanakan tugas yang ada di kantor desa maupun di lingkungan masyarakat Desa Wanakerta Bungursari Purwakarta.

5. Bidang Pendidikan dan Kesehatan. Pendidikan dan kesehatan merupakan hal yang sangat penting dimiliki oleh masyarakat Desa Wanakerta Kecamatan Bungursari Purwakarta. Dengan adanya PKM yang mengadakan kegiatan mengajar bahasa Inggris, les atau pelajaran tambahan, sosialisasi kesehatan, dan senam ini warga lebih terbantu dalam meningkatkan pengetahuan kepada anak-anak juga mengetahui pentingnya menyikat gigi dan berolahraga untuk kesehatan manusia. Masyarakat berharap untuk selanjutnya akan ada program atau kegiatan yang dapat memberikan kontribusi dalam meningkatkan pengetahuan masyarakat. 


\section{KESIMPULAN}

Pelaksanaan pendampingan dan pengembangan masyarakat merupakan salah satu tujuan dari kegiatan PKM yang diharapkan mampu untuk dapat menyelesaikan permasalahan yang ada di masyarakat Desa Wanakerta Kecamatan Bungursari Kabupaten Purwakarta Jawa Barat, baik di bidang perekonomian, keagamaan, sosial dan budaya, pemerintahan desa, maupun di bidang pendidikan dan kesehatan. Melalui pendampingan terhadap masyarakat, kegiatan PKM ini melakukan penggalian data tentang persoalan atau kondisi masyarakat sekitar yang selanjutnya dirumuskan dalam bentuk program kerja dan realisasinya yang diharapkan dapat menjawab persoalan yang ada bersama dengan masyarakat. Kemudian program kerja yang dirumuskan telah terealisasi kurang lebih $90 \%$ sesuai dengan kemampuan peserta PKM, meskipun masih terdapat kendala dalam pelaksanaannya.

\section{DAFTAR PUSTAKA}

Akil, Nasriah. "Strategi Pengembangan Ekonomi Kreatif Kabupaten Wajo." Jurnal BISNIS \& KEWIRAUSAHAAN 4, no. 4 (2015): 404-415.

Anggraeni, Lisa Dewi, Moch. Cahyo Sucipto, and Siti Rohmat. "Analisis Faktor Yang Mempengaruhi Masyarakat Muslim Menggunakan Jasa 'Bank Emok' Di Desa Cilalawi Kecamatan Sukatani Kabupaten Purwakarta." EKSISBANK (Ekonomi Syariah dan Bisnis Perbankan) 4, no. 2 (2018).

Azizah, Siti Nur, and Muhfiatun Muhfiatun. "Pengembangan Ekonomi Kreatif Berbasis Kearifan Lokal Pandanus Handicraft Dalam Menghadapi Pasar Modern Perspektif Ekonomi Syariah (Study Case Di Pandanus Nusa Sambisari Yogyakarta)." Aplikasia: Jurnal Aplikasi Ilmu-ilmu Agama 17, no. 2 (February 12, 2018): 63. http:// ejournal.uin-suka.ac.id/pusat/aplikasia/article/view/1273.

Jalaludin, Jalaludin, and Heru Komarujaman. "Talent Management Dalam Meningkatkan Kinerja Lembaga KSPPS BMT Mitra Sadaya Cabang Purwakarta." EKSISBANK: Ekonomi Syariah dan Bisnis Perbankan 2, no. 1 (June 25, 2018). http://journal.sties-purwakarta.ac.id/index.php/EKSISBANK/article/view/9.

Nugroho, Sigit, and Sujadmi Sujadmi. "Perlindungan Hukum Dan Analisis Potensi

Desain Industri Pada Ekonomi Kreatif Yang Berbasis Ilmu Pengetahuan Yang Dihasilkan Oleh Umkm Di Kota Pangkalpinang." PROGRESIF: Jurnal Hukum 10, no. 2 (August 20, 2018). https://journal.ubb.ac.id/index.php/progresif/article/view/194.

Sitorus, Budi, and Tulus Irfan Harsono Sitorus. "Dukungan Transportasi Logistik Dan Daya Saing Indonesia Dalam Menghadapi Masyarakat Ekonomi Asean." JURNAL MANAJEMEN TRANSPORTASI DAN LOGISTIK 4, no. 2 (September 11, 2017): 137. http://ejournal.stmttrisakti.ac.id/index.php/jmtranslog/article/view/70. 
Sucipto, Moch Cahyo. "The Human Rights In Islam (The Study Of Al-Muwafaqat By Imam Al-Syathibi)." EKSISBANK (Ekonomi Syariah dan Bisnis Perbankan) 2, no. 2 (2018): 1-5. 